\title{
Politik Hukum Pemberantasan Tindak Pidana Narkotika di Masa Pandemi Covid-19 (Studi Polda Sumut)
}

\section{The Political Law of Eradicating Narcotics Crime during the Covid-19 Pandemic (North Sumatra Police Study)}

\author{
Rahmad Gaol Hasibuan, Rizkan Zulyadi \& M Citra Ramadhan* \\ Program Magister Hukum, Pasca Sarjana, Universitas Medan Area, Indonesia \\ Diterima: 07 Mei 2021 Direview: 07 Mei 2021; Disetujui: 20 September 2021
}

*Coresponding Email:

\begin{abstract}
Abstrak
Kejahatan narkotika termasuk dalam kejahatan luar biasa (extraordinary crime). Kasus penyalahgunaan narkotika selama masa pandemi ini semakin meningkat, dari tahun 2019 hingga tahun 2020. Peningkatan peredaran narkotika di masa pandemi covid 19 ini terlihat dari bertambahnya jumlah barang bukti narkotika hasil tangkapan yang semakin tinggi. ini bertujuan untuk mengetahui modus operandi kejahatan peredaran dan penyalahgunaan narkotika pada masa pandemi Covid-19. Metode penelitian yang digunakan adalah yuridis normatif. Data yang digunakan adalah data sekunder yang terdiri dari bahan hukum primer, sekunder dan tersier. Analisis data kualitatif dipergunakan dalam menganalisis permasalahan. Hasil penelitian menemukan bahwa pertama, Modus operandi kejahatan peredaran dan penyalahgunaan narkotika pada masa pandemi Covid 19 telah berkembang yaitu dengan pengiriman tiga botol narkotika berupa cairan dari China berisi $10 \mathrm{ml}$ yang bertuliskan Hemp Oil, Penyalahgunaan narkoba dilakukan di rumah, apartemen, maupun hotel sifatnya home session, Modus operandi menggunakan jasa pos dan ekspedisi kebeberapa daerah, dan melalui Online dengan website, selain itu modus peredaran dengan transportasi logistik pertanian, seolah-oleh mengirimkan barang untuk kebutuhan masyarakat.
\end{abstract}

Kata Kunci: Politik Hukum; Peredaran Narkotika; Pancemi Covid 19

\begin{abstract}
Narcotics crimes are included in extraordinary crimes (extraordinary crime). Cases of narcotics abuse during this pandemic are increasing, from 2019 to 2020. The increase in narcotics circulation during the COVID-19 pandemic can be seen from the increasing number of evidence of narcotics being caught which is getting higher. This study aims to determine the modus operandi of narcotics trafficking and abuse during the Covid-19 pandemic. The research method used is normative juridical. The data used is secondary data consisting of primary, secondary and tertiary legal materials. Qualitative data analysis is used in analyzing the problem. The results of the study found that first, the modus operandi of narcotics trafficking and abuse during the Covid-19 pandemic had developed, namely by sending three bottles of narcotics in the form of liquid from China containing $10 \mathrm{ml}$ which read Hemp Oil, Drug abuse is carried out in homes, apartments, and hotels. session, the modus operandi is to use postal and expedition services to several areas, and via online with a website, besides that, the mode of circulation is by means of agricultural logistics transportation, as if sending goods for the needs of the community.
\end{abstract}

Keywords: Legal Politics; Narcotics Circulation; Covid Pandemic 19

How to Cite: Hasibuan, R.G. Zulyadi, R. \& Ramadhan. M.C. (2021). Politik Hukum Pemberantasan Tindak Pidana Narkotika Dimasa Pandemi Covid-19 (Studi Polda Sumut). Journal of Education, Humaniora and Social Sciences (JEHSS). 4 (2): 650-659 


\section{PENDAHULUAN}

Sampai saat sekarang ini pemerintah Republik Indonesia baik di tingkat pusat maupun di tingkat daerah telah berupaya untuk mengatasi pandemi corona dan meminimalisir korban jiwa yang diakibatkan oleh pandemi corona, seperti dengan menerapkan himbauan agar masyarakat menjaga jarak dalam berinteraksi (Social Distancing), Pembatasan Sosial Berskala Besar (PSBB) di beberapa daerah yang mengajukan PSBB kepada menteri kesehatan, mewajibkan warga menggunakan masker saat keluar rumah, melakukan penyemprotan disinfektan, larangan mudik, penutupan ataupun pembatasan kegiatan usaha atas beberapa jenis usaha yang dapat menyebabkan orang berkumpul secara terkonsentrasi (seperti warung internet, kafe, restoran, hotel, pusat perbelanjaan dan lain-lain) sosialisasi pencegahan pandemi corona, bekerja dari rumah (work from home), sekolah dan belajar di rumah, dan berbagai kebijakan terkait percepatan penanganan pandemi corona lainnnya(Rizkan: 2020).

Pemerintah memperkuat kewajiban physical distancing melalui Peraturan Pemerintah Nomor 21 Tahun 2020 tentang Pembatasan Sosial Berskala Besar (PSBB) dan Peraturan Kementerian Kesehatan (Permenkes) No. 9 Tahun 2020. Aturan ini harus dipatuhi dan untuk memastikan kepatuhan tersebut, Polri menjadi garda terdepan. Dalam konteks inilah, selain tenaga medis, Polri dapat disebut sebagai garda terdepan dalam upaya pencegahan penyebaran COVID-19. Keberhasilan PSBB memang tergantung dari kesadaran dan kedisiplinan masyarakat, namun untuk memastikan keduanya berjalan, diperlukan peran Kepolisian Republik Indonesia (Polri) di dalamnya.

Pada bulan April 2020, Polda Sumut berhasil menggagalkan penyeludupan narkoba jenis sabu yang masuk melalui Aceh ke Kota Medan dengan jaringan Internasional. Penyelundupan narkoba jenis sabu menggunakan bungkus teh hijau China, kali ini modus baru penyelundupan dilakukan menggunakan bungkus Kopi Gayo. Modus baru diungkap Direktorat Reserse Narkoba Polda Sumut. Dalam operasi ini, sabu seberat 4 kilogram diamankan, 4 orang pelaku ditangkap, 1 diantaranya ditembak mati karena mencoba lari dan melawan petugas (Reza Efendi:2020).

Pada bulan April 2020, Personel Sat Reskrim Polres Tanjung Balai mengamankan dua orang warga yang menjual narkotika jenis sabu seberat 2,28 gram di saat pandemi Virus Corona (COVID19). (Sirait \& Rafiqi, 2018). Petugas langsung melakukan penangkapan terhadap tersangka TU dan menyita satu lembar amplop warna merah di dalamnya berisi 5 bungkus plastik klip kecil transparan diduga berisi sabu seberat 0,61 gram dan satu unit timbangan elektrik warna hitam. Sedangkan dari tersangka ER, petugas menyita satu bungkus plastik transparan berisi narkotika jenis sabu seberat 2,28 gram, dan 1 unit handphone (Munawar :2020).

Pada Bulan Agustus 2020, di Kota Medan berdasarkan informasi yang diperoleh dari www.msn.com bahwa Badan Narkotika Nasional (BNN) berhasil menggagalkan upaya peredaran 47 kilogram sabu yang disisipkan ke dalam truk pengangkut kelapa yang melakukan perjalanan dari Aceh menjuju Kota Palembang. Petugas berhasil mengamankan truk saat melintas di seputaran gerbang tol Helvetia Medan. Sekilas, truk yang diberhentikan hanyalah truk biasa. Dalam kasus ini, 4 pelaku berhasil ditangkap. Satu diantaranya merupakan narapidana di salah satu lembaga pemasyarakatan di Kota Palembang. (Humendru dkk, 2020; Butar-butar dkk, 2020).

Pengungkapan kasus tersebut mengindikasikan bahwa perdagangan narkoba terus terjadi di tengah covid 19, upaya penegakan hukum belum mampu menghentikan niat para pelaku hal ini disebabkan karena permintaan (demand) yang tinggi sehingga penawaran (supply) juga akan meningkat (Adhitya, 2020). Peredaran narkoba tetap menjadi ancaman utama di Indonesia di tengah pandemi Covid-19.

Modus dan strategi dari para Bandar/Penggedar narkoba terus berkembang dengan caracara baru dan media baru sehingga para aparatur penegak hukum tidak dapat mendeteksi peredaran narkoba yang dilakukan. Penyalahgunaan narkoba di tengah pandemi covid-19 akan menjadi masalah baru karena penyebaran covid 19 tidak dapat berdamai dengan siapapun, sehingga harus dicarikan solusinya. Stabilitas sosial, ekonomi, politik dan keamanan nasional akan terganggu manakala muncul ancaman Kejahatan dalam skala kecil maupun besar. Pada masa pandemic COVID-19 saat ini diperlukan adanya langkah-langkah pencegahan, disamping 
penegakan hukum (Millah, 2020). Pengungkapan jaringan bisnis narkoba tidaklah mudah karena dilakukan dengan terstruktur dan rapi, upaya terus dilakukan agar dapat menghentikan peningkatan kasus penyalahgunaan narkoba, berbagai macam alasan yang diungkapkan oleh para pelaku ketika sudah ditangkap oleh aparat penegak hukum, namun alasan tersebut dibuat agar terbebas dari jeratan hukum.

Melalui Undang-Undang Narkotika yaitu UU No. 35 Tahun 2009, seharusnya dapat mencegah dan menekan meningkatnya peredaran serta penggunaan narkotika di wilayah Indonesia, akan tetapi kenyataannya bahwa dengan undang-undang tersebut hingga saat ini persoalan peredaran dan penyalahgunaan narkotika belum dapat teratasi. Adanya dua lembaga seperti Kepolisian Republik Indonesia dengan Badan Narkotika Nasional hanya mampu melakukan penegakan hukum represif terhadap para pelaku pengedar dan pemakai narkoba, tetapi hingga saat ini belum dapat dituntaskan penangannnya. (Simangunsong, 2014)

Kejahatan penyalahgunaan narkoba adalah jenis kejahatan yang tidak terjadi secara seketika namun terjadi melalui proses sehingga para pelaku dengan penuh kesadaran memahami sanksi hukum yang akan diberikan terhadap perbuatan yang dilakukannya, alasan ketidaktahuan dari para pelaku penyalahgunaan narkoba atas undang-undang tidak dapat dimaafkan (ignorantia jurist non excusat), perbuatan tersebut juga terjadi bukan merupakan peristiwa hereditas (bawaan sejak lahir, warisan), kejahatan merupakan suatu konsepsi yang bersifat abstrak, dimana kejahatan tidak dapat diraba dan dilihat kecuali akibat dari kejahatan tersebut (Beridiansyah, 2020).

Berdasarkan pendapat dari Sheila Natalia dan Sahadi Humaedi bahwa Permasalahan mengenai NAPZA memang masih menjadi suatu hal yang bersifat kompleks. Mengingat urgensinya yang tidak bisa dipungkiri lagi bahwa jika penggunaanya tidak bijak dan dibiarkan dapat merugikan dan sangat membawa dampak yang buruk bagi orang yang menjadi korbannya. Bukan hanya membawa dampak buruk bagi orang yang menjadi korbannya saja, penyalahgunaan NAPZA ini juga dapat mengancam pihak-pihak yang ada disekitarnya. Ditambah, persebaran NAPZA ini sendiri cukup sulit dikontrol. Para pengedar dan pemakai seperti tidak mengenal keadaan dan situasi, seperti contohnya pada saat ini. Pada masa pandemi covid-19. Peredaran NAPZA di tengah pandemi Covid-19 ini menjadi semakin serius. Mengingat tidak hanya satu masalah saja yang sedang dihadapi, melainkan dua masalah sekaligus. Peredaran NAPZA yang masih berjalan dan Pandemi Covid-19. Pemakaian NAPZA pada masa pandemi seperti saat ini akan lebih membahayakan dua kali lipat daripada kondisi normal (Natalia \& Humaedi, 2020).

Lahirnya Instruksi Presiden Nomor 6 tahun 2018 menegaskan bahwa Pemberantaan peredaran dan penyalahgunaan narkoba telah memberikan dimensi luas dan kompleks baik dari sudut medik, psikiatri, kesehatan jiwa, maupun psikososial dan diseluruh jajaran pemerintah dan seluruh komponen untuk bersama melakukan pencegahan terhadap bahaya narkoba.

Adanya Intruksi Presiden No 6 tahun 2018 semangat pemberantasan tindak pidana narkotika, sehingga Undang-Undang Nomor 35 Tahun 2009, tidak hanya mengatur pemberantasan sanksi pidana bagi penyalahgunaan narkotika saja, tetapi juga bagi penyalahgunaan precursor narkotika untuk pembuatan narkotika.Perataan sanksi pidana ini diwujudkan dalam bentuk pidana minimum khusus, pidana penjara 20 tahun, pidana penjara seumur hidup , maupun pidana mati yang didasarkan pada golongan, jenis, ukuran dan jumlah narkotika, dengan harapan adanya pemberatan sanksi pidana ini maka pemberantasan tindak pidana narkotika menjadi efektif serta mencapai hasil maksimal. Adanya sinergitas antara lembaga Pemerintah, Lembaga Penegak Hukum dan Masyarakat merupakan titik pangkal keberhasilan pemberantasan peredaran dan penyalahgunaan narkotika di Indonesia khususnya di Sumatera Utara.

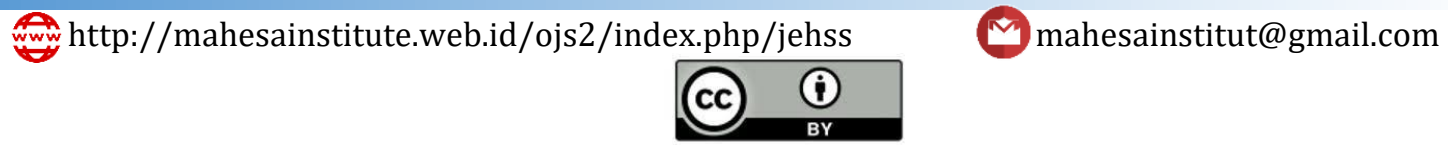


Berdasarkan latar belakang diatas, penulis tertarik untuk melakukan kajian terhadap pemberantasan peredaran narkotika di sumatera Utara pada masa Pandemi Covid 19. Penelitian ini berjudul Politik Hukum Pemberantasan Tindak Pidana Narkotika Dimasa Pandemi Covid-19 (Studi Kepolisian Daerah Sumatera Utara). Berdasarkan latar belakang diatas, maka yang menjadi permasalahan dalam penelitian ini adalah Bagaimana modus operandi kejahatan peredaran dan penyalahgunaan narkotika pada masa pandemi Covid $19 ?$

\section{METODE PENELITIAN}

Jenis penelitian yang dilakukan dalam penyusunan tesis ini adalah penelitian yuridis normatif (Abdurrahman: 2009). Penelitian yuridis normatif yaitu penelitian yang difokuskan untuk mengkaji penerapan kaedah-kaedah atau norma-norma hukum positif (Johny Ibrahim, 2008) Sifat penelitian dalam penelitian ini adalah bersifat deskriptif analitis, penelitian bersifat deskriptif analitis merupakan suatu penelitian yang menggambarkan, menelaah, menjelaskan, dan menganalisis suatu peraturan hukum. Sumber data yang digunakan dalam penelitian ini adalah data sekunder yang berupa bahan hukum primer, bahan hukum sekunder dan bahan hukum tersier(Marzuki, 2006). Metode pengumpulan data yang digunakan dalam penelitian ini adalah Penelitian Kepustakaan (Library Reseaarch) dan Penelitian Lapangan (Field Research). Keseluruhan data dalam penelitian ini dianalisis secara kualitatif. Analisis kualitatif ini akan dikemukakan dalam bentuk uraian yang sistematis dengan menjelaskan hubungan antara berbagai jenis data. Selanjutnya semua data diseleksi dan diolah, kemudian dianalisa secara deskriptif sehingga selain menggambarkan dan mengungkapkan, diharapkan akan memberikan solusi atas permasalahan dalam penelitian ini(Abdurrahman, 2009).

\section{HASIL DAN PEMBAHASAN \\ Modus Operandi Kejahatan Peredaran dan Penyalahgunaan narkotika pada masa pandemi Covid 19}

Kejahatan terkait narkotika termasuk dalam kejahatan luar biasa (extraordinary crime). Berdasarkan data yang didapat dari Informasi internal Polri dan juga media massa. Badan Reserse Kriminal Polri selama masa pandemi Covid 19 kasus penyalahgunaan narkotika selama masa pandemi ini semakin meningkat, dari tahun 2019 hingga tahun 2020. Peningkatan peredaran narkotika di masa pandemi covid 19 ini terlihat dari bertambahnya jumlah barang bukti narkotika hasil tangkapan yang semakin tinggi. Pada tahun 2019, Polri mengungkap 2,7 Ton Barang Bukti Sabu.

Provinsi Sumatera Utara sebagai daerah kedua tertinggi peredaran narkotika juga sangat mengkhawatirkan karena akan berdampak pada daerah-daerah lain yang berdekatan dengan Provinsi Sumatera Utara. Pada masa pandemi Covid 19, didapatkan bahwa peredaran narkotika yang terjadi di Sumatera Utara semakin marak terjadi walaupun dalam kondisi pandemi covid 19 melanda masyarakat. Tidak hanya melibatkan orang dewasa dalam kasus narkotika, tetapi juga anak-anak juga menjadi bagian dari tindak pidana narkotika. Berdasarkan data yang disampaikan oleh Badan Narkotika Nasional (BNN) Provinsi Sumatera Utara, sepanjang tahun 2020, BNN berhasil mengungkap Kasus Peredaran Narkotika dengan Jumlah berkas perkara tindak pidana narkotika yang P-21 berjumlah 96 berkas dan yang masih tersangka sebanyak 111 orang.

Berdasarkan data yang disampaikan BNN Provinsi Sumut bahwa Pengungkapan kasus in mengalami peningkatan dari sebelumnya di 2019 yang hanya sebanyak 71 kasus, dengan jumlah tindak pidana narkotika P-21 sejumlah 85 berkas dengan jumlah tersangka sebanyak 106 orang. Sementara Untuk Barang bukti yang berhasil disita selama 2020 yakni sabu seberat $30.231,02$ gram, ekstasi sebanyak 1.160,5 butir, ganja seberat 303.972,2 gram. Menurut Ungkap kepala BNNP Sumut Brigjen pol Atrial bahwa Jumlah tangkapan barang bukti ini mengalami penurunan pada 
Rahmad Gaol Hasibuan, Rizkan Zulyadi, \& M Citra Ramadhan, Politik Hukum Pemberantasan Tindak Pidana

tahun sebelumnya1. Berdasarkan data yang diperoleh dari Kepolisian Daerah Sumatera Utara (Polda Sumut) bahwa ditahun 2020, Polda Sumut berhasil mengungkap 6.863 kasus penyalahgunaan narkoba. Dari pengungkapan ini, berhasil disita 702,5 kilogram sabu dan telah dilakukan penindakan Polda Sumut dan jajaran. Selama 2020, 8.925 tersangka telah diamankan, jumlah ini naik 15 persen dari tahun sebelumnya.

Tabel. 1. Data Kasus Narkoba di Polres-Polres Se Sumatera Utara Tahun 2019

\begin{tabular}{|c|c|c|c|c|}
\hline \multirow[t]{2}{*}{ NO } & \multirow[t]{2}{*}{ WILAYAH } & \multicolumn{3}{|c|}{ KETERANGAN } \\
\hline & & JTP & JPTP & TSK \\
\hline $\mathbf{1}$ & Polrestabes Medan & 2.117 & 1.827 & 2.805 \\
\hline 2 & Polres Tebing Tinggi & 118 & 102 & 133 \\
\hline 3 & Polres Deli Serdang & 295 & 305 & 374 \\
\hline 4 & Polres Binjai & 194 & 188 & 227 \\
\hline 5 & Polres Langkat & 529 & 454 & 657 \\
\hline 6 & Polres Simalungun & 212 & 212 & 303 \\
\hline 7 & Polres Asahan & 314 & 304 & 421 \\
\hline 8 & Polres Labuhan Batu & 574 & 540 & 669 \\
\hline 9 & Polres Tapanuli Tengah & 70 & 53 & 94 \\
\hline 10 & Polres Tapanuli Utara & 31 & 23 & 36 \\
\hline 11 & Polres Tapanuli Selatan & 91 & 106 & 137 \\
\hline 12 & Polres Mandailing Natal & 66 & 56 & 83 \\
\hline 13 & Polres Tanah Karo & 142 & 149 & 194 \\
\hline 14 & Polres Dairi & 29 & 37 & 34 \\
\hline 15 & Polres Nias & 21 & 20 & 27 \\
\hline 16 & Polres Pel. Belawan & 459 & 289 & 568 \\
\hline 17 & Polres Serdang Bedagai & 195 & 192 & 239 \\
\hline 18 & Polres P. Siantar & 146 & 152 & 201 \\
\hline 19 & Polres Tanjung Balai & 199 & 248 & 232 \\
\hline 20 & Polres Sibolga & 54 & 51 & 79 \\
\hline 21 & Polres P. Sidempuan & 77 & 73 & 113 \\
\hline 22 & Polres Toba Samosir & 22 & 17 & 35 \\
\hline 23 & Polres Samosir & 11 & 10 & 20 \\
\hline 24 & Polres Humbahas & 7 & 6 & 7 \\
\hline 25 & Polres Nias Selatan & 13 & 12 & 15 \\
\hline 26 & Polres Pak - Pak Barat & 10 & 7 & 13 \\
\hline 27 & Polres Batubara & 166 & 158 & 218 \\
\hline & Jumlah & 6.162 & $5 \cdot 591$ & $7 \cdot 934$. \\
\hline
\end{tabular}

\section{Sumber: Direktorat Narkoba Polda Sumut.2019}

Pada masa pandemi covid 19, peredaran narkotika tidak hanya dilakukan oleh masyarakat umum saja, tetapi juga di Institusi Polri terdapat keterlibatan anggota Polri dalam peredaran narkotika, baik sebagai pemakai atau penggedar. Di Polda Sumatera Utara, di tahun 2020 terdapat 
beberapa tindakan tegas dari Kapolda kepada para anggota Polri yang terlibat dalam peredaran dan penyalahgunaan narkotika. Kepolisian Daerah Sumatera Utara memecat sedikitnya 53 personel dengan sanksi pemberhentian dengan tidak hormat (PDTH) akibat terlibat berbagai penyimpangan dan pelanggarana berupa penyalahgunaan narotika.

\begin{tabular}{|c|c|c|c|c|}
\hline \multirow[t]{2}{*}{ No } & \multirow[t]{2}{*}{ WILAYAH } & \multicolumn{3}{|c|}{ KETERANGAN } \\
\hline & & JTP & JPTP & TSK \\
\hline $\mathbf{1}$ & Ditresnarkoba Poldasu & 531 & 369 & 729 \\
\hline 2 & Polrestabes Medan & 2350 & 2403 & 3181 \\
\hline 3 & Polres Tebing Tinggi & 176 & 162 & 200 \\
\hline 4 & Polres Deli Serdang & 311 & 326 & 381 \\
\hline 5 & Polres Binjai & 299 & 310 & 360 \\
\hline 6 & Polres Langkat & 374 & 427 & 451 \\
\hline 7 & Polres Simalungun & 169 & 164 & 222 \\
\hline 8 & Polres Asahan & 299 & 309 & 415 \\
\hline 9 & Polres Labuhan Batu & 468 & 527 & 569 \\
\hline 10 & Polres Tap. Tengah & 91 & 93 & 122 \\
\hline 11 & Polres Tap. Utara & 23 & 35 & 39 \\
\hline 12 & Polres Tap. Selatan & 98 & 111 & 137 \\
\hline 13 & Polres Madina & 103 & 91 & 144 \\
\hline 14 & Polres Tanah Karo & 221 & 270 & 254 \\
\hline 15 & Polres Dairi & 42 & 50 & 57 \\
\hline 16 & Polres Nias & 25 & 21 & 31 \\
\hline 17 & Polres Pel. Belawan & 542 & 506 & 681 \\
\hline 18 & Polres Sergai & 326 & 235 & 409 \\
\hline 19 & Polres P. Siantar & 181 & 212 & 252 \\
\hline 20 & Polres Tanjung Balai & 149 & 163 & 189 \\
\hline 21 & Polres Sibolga & 69 & 65 & 90 \\
\hline 22 & Polres P. Sidempuan & 107 & 90 & 129 \\
\hline 23 & Polres Toba & 37 & 40 & 53 \\
\hline 24 & Polres Samosir & 10 & 11 & 18 \\
\hline 25 & Polres Humbahas & 11 & 10 & 19 \\
\hline 26 & Polres Nias Selatan & 11 & 10 & 12 \\
\hline 27 & Polres Pak - Pak Barat & 8 & 8 & 12 \\
\hline 28 & Polres Batubara & 218 & 216 & 275 \\
\hline \multirow[t]{2}{*}{29} & Polres Palas & 39 & 31 & 40 \\
\hline & Jumlah & 7288 & 7265 & 9471 \\
\hline
\end{tabular}

Sumber: Direktorat Narkoba Polda Sumut tahun 2020

Penegakan terhadap hukum di tengah masyarakat tidak dapat dipisahkan dari karakter hukum suatu negara. karakter hukum yang bersifat konservatif, korektif, dan inovatif serta aspiratif akan sanga berpengaruh dalam penegakan hukum. Hukum merupakan rambu-rambu perilaku anggota masyarakat dan sekaligus menyediakan sanksi. Maka hukum sudah seharusnya berlaku dalam jangka panjang dan juga tidak imun dengan perubahan masyarakat menurut waktu dan tempat (Romli Atmasasmita:2017). Pendapat Van Kan bahwa hukum selalu tertinggal dari perkembangan masyarakat memang ada benarnya, tetapi pendapat tersebu telah dijawab oleh Mochtar Kusumaatmadja bahwa hukum harus ditempatkan didepan dan membawa arah perubahan masyarakat menjadi lebih modern, atau lebih baik dari masa sebelumnya. Namun, Mochtar juga tidak menjelaskan bahwa ke arah mana pembangunan hukum nasional akan diwujudkan dan masyarakat Indonesia yang seperti apa yang akan diwujudkan dengan perananan hukum seperti itu. 
Adanya,UU No. 35 tahun 2009 dan peraturan pelaksanannya ternyata belum mampu memberikan efek jera bagi para pelaku peredaran gelap narkotika. Ditambah dengan kebijakan kriminal yang dibentuk oleh Pemerintah Indonesia dengan melakukan perjanjian internasional terkait dengan pemberantasan narkotika hanya sebatas diatas kertas dan pencitraan diplomatik bagi negara-negara lain. Misalnya, dalam pemberantasan peredaran gelap narkoba internasional, masyarakat internasional telah banyak membentuk kerja sama internasional, seperti melalui Interpol, Europol, ASEANAPOL, ASOD (ASEAN Senior Official on Drugs Matters), dan lain-lain. Selain tentunya melalui wadah Badan Anti-Narkoba PBB (UNODC). Dalam wadah atau forum multilateral tersebut biasanya dibahas berbagai upaya kerja sama untuk memberantas peredaran gelap narkoba dalam lingkup yang lebih luas, baik di suatu kawasan maupun tingkat global (Azmi \& Rani, 2017).

\section{Faktor-faktor yang melatarbelakangi kejahatan kejahatan peredaran narkotika yang terbaru di masa pandemi covid 19 di Indonesia}

Para pelaku kejahatan dapat melakukan aksinya dengan berbagai upaya dan berbagai cara. Keadaan seperti itu yang disebut dengan istilah "modus operandi" (model pelaksanaan kejahatan). Dengan kemajuan teknologi dewasa ini, modus operandi para penjahat juga mengarah kepada kemajuan ilmu dan teknologi. Faktor-faktor yang melatarbelakangi kejahatan, menurut Mulyana W. Kusumah pada dasarnya dapat 7 dikelompokkan ke dalam 4 (empat) golongan faktor, yaitu: (Mulyana:1991)

1. Faktor dasar atau faktor sosio-struktural, yang secara umum mencakup aspek budaya serta aspek pola hubungan penting di dalam masyarakat.

2. Faktor interaksi sosial, yang meliputi segenap aspek dinamik dan prosesual di dalam masyarakat, yang mempunyai cara berfikir, bersikap dan bertindak individu dalam hubungan dengan kejahatan;

3. Faktor pencetus (precipitating factors), yang menyangkut aspek individu serta situasional yang berkaitan langsung dengan dilakukannya kejahatan.

4. Faktor reaksi sosial yang dalam ruang lingkupnya mencakup keseluruhan respon dalam bentuk sikap tindakan dan kebijaksanaan yang dilakukan secara melembaga oleh unsur unsur sistem peradilan pidana khususnya dan variasi respons, yang secara "informal" diperlihatkan oleh warga masyarakat

Di tahun 2021 ini, berdasarkan data informasi yang dihimpun dari keterangan Kepala Badan Narkotika Nasional (BNN) Irjen Pol Petrus Reinhard Golose mengatakan peredaran narkotika di dalam negeri meningkat di tengah pandemi Covid-19. Meningkatnya peredaran diduga akibat work from home. Petrus menyampaikan hal tersebut dalam Rapat Dengar Pendapat dengan Komisi III DPR. Menurutnya, peningkatan peredaran terlihat juga dari meningkatnya barang bukti. Sebagai contoh barang bukti sabu atau methamphetamine yang hanya diperoleh dalam tiga bulan terakhir ini Maret 2021, 808,67 kilogram atau 70,19 persen dibanding kan dengan jumlah barang bukti tahun 2020 sebanyak 1.152,2 kilogram," kata Petrus. Menurut Petrus, penyitaan barang bukti ganja juga meningkat hingga bulan Maret 2021. Dimana dari tahun lalu meningkat hingga 143 persen. Demikian juga barang bukti ganja sampai tahun 2021 sampai bulan Maret 2021 sebanyak 3.462,75 kilogram atau meningkat 143,64 persen dibandingkan barang bukti tahun 2020 sebanyak 2.410 kilogram ini yang baru dilakukan oleh institusi BNN. Menurut Petrus bahwa dilihat dari meningkatnya jumlah barang bukti yang disita oleh BNN meningkat, makin memperlihatkan permintaan juga meningkat. Permintaan narkotika meningkat akibat penerapan work from home atau kerja dari rumah. 
Munculnya narkoba jenis baru atau New Psychoactive Substances (NPS) dan modus modus yang selalu update mengikuti perkembangan zaman dan tren masyarakat. Apalagi di era pandemic ini tidak melunturkan semangat para bandar untuk mencari mangsa dengan memanfaatkan jasajasa pengiriman ataupun media online untuk mengedarkan narkobanya. Hal tersebut apabila didiamkan maka akan menimbulkan dampak yang sangat besar bagi masyarakat dan para generasi muda/milenial sehingga menjadi hancur masa depannya. Untuk itulah diperlukan kepedulian dari seluruh komponen masyarakat dan sinergi antara instansi dan masyarakat agar dapat memutuskan tali rantai antara Suplay dan Demand.

Beberapa perkembangan modus operandi kejahatan peredaran narkotika yang terbaru di masa pandemi covid 19 yakni diantaranya:

1. Seperti di Sumatera Utara, petugas Bea Cukai Kualanamu Deli Serdang menggagalkan pengiriman tiga botol narkotika berupa cairan dari China berisi $10 \mathrm{ml}$ yang bertuliskan Hemp Oil yang dicurigai merupakan Tetrahydrocannabinol.

2. Sebelum pandemi, kasus penyalahgunaan narkoba banyak ditemui di tempat-tempat hiburan. Namun, karena tempat hiburan ditutup, penyalahgunaan narkoba kini banyak dilakukan di rumah, apartemen, maupun hotel. "Jadi menurut hasil pengungkapan kami itu tidak lagi di tempat hiburan, tapi banyak yang melakukan aktivitas (penyalahgunaan narkoba) di apartemen, hotel, sifatnya home session. Dengan adanya perubahan modus operandi ini, pengungkapan penyalahgunaan narkoba dapat terlaksana berkat laporan masyarakat

3. Modus operandi baru peredaran narkotika dalam kuantitas kecil saat ini menggunakan jasa pos dan ekspedisi kebebera daerah di Indonesia. Modus operandi tersebut untuk wilayah sumatera utara marak terjadi, dan rutin digunakan oleh para pelaku peredaran narkotika untuk menyampaikan pesanan narkotika dari pemakai. Modus Pemesanan narkotika saat ini dilakukan melalui tren daring (online) website. Ini menjadi tren bahwa peredaran dan transaksi narkoba dilakukan secara daring dan juga dtemukan di dark web.

4. Modus operandi dalam wilayah lokal di sumatera utara, para pengedar narkotika memanfaatkan situasi pandemi covid 19 untuk bertransaksi narkotika menggunakan transportasi logistik pertanian, seperti jagung, kelapa, pisang atau beras dengan seolah-oleh mengirimkan barang untuk kebutuhan masyarakat ke suatu daerah.

Di masa pandemi covid 19 ini, perhatian bangsa Indonesia di fokuskan pada penceghan dan pemulihan keadaan masyarakat akibat terkena virus corono. Di tengah gencarnya perhatian bangsa ini akan wabah virus Corona (Covid-19) yang makin hari semakin masif, ada satu hal yang tak boleh terlupakan, yakni bahaya penyalahgunaan narkoba yang terus merusak anak bangsa negeri ini. Ancaman narkoba yang lebih berbahaya dimasa depan juga belum berakhir. Dalam sebulan terakhir ini saja Badan Narkotika Nasional bersama Bea dan Cukai menggagalkan peredaran gelap narkoba jenis shabu jaringan Aceh-Medan dengan barang bukti sebanyak $32 \mathrm{Kg}$ di Asahan, Sumatera Utara. Ditambah lagi ditengah pandemik corona ini ada sederet artis tanah air yang lagi-lagi terciduk kasus narkoba. Hal ini sungguh sangat memprihatinkan. Karena pada situasi pandemi covid-19 yang masih melanda negeri ini, telah banyak hal yang membuat aktivitas kita terhenti, namun di sisi lain masalah peredaran gelap dan penyalahgunaan narkoba tidak pernah berhenti di Negara kita. Meski demikian, dalam konteks upaya penanggulangan narkoba, masyarakat perlu dan harus terus diingatkan bahwa ancaman narkoba sudah sejak awal sebelum serangan virus corona ini muncul.

Di tengah masa darurat covid-19 tentunya dampaknya terhadapat ekonomi masyarakat kecil dan menengah tentunya sangatlah dirasakan (Siregar, 2020). Ditengah beralihnya fokus pemerintah dalam penanganan Covid-19 ini, krisis ekonomi yang dirasakan, meningkatnya jumlah pengangguran dan bertambahnya tenaga kerja yang di PHK, tentunya dapat menjadi azas manfaat bagi para bandar narkoba untuk mengsuplai dan memperdagangkan barang haram tersebut. Hal ini yang harus benar-benar kita waspadai. Ketidak pahaman masyarakat mengenai narkoba dan resikonya dapat menjadi celah para bandar dalam memasarkan barang haram ini. Iming-iming ditengah masa Covid-19 ini ekonomi semakin sulit, tingkat stres masyarakat karena Covid-19 yang tinggi, sulitnya mencari pekerjaan, sudah tentu masyarakat yang tidak mengetahui dampak 
buruknya dan berfikir pendek dapat diperdaya dan dibohongi oleh pihak yang tidak bertanggung jawab (bandar \& pengedar). Jangan sampai masyarakat yang sehat lengah malah menjadi kurir narkoba.

Di sini akhirnya kita dapat menyadari bahwa penyuluhan dan informasi di masyarakat mengenai bahaya peredaran gelap dan penyalahgunaan narkoba serta Covid-19 sampai saat ini belumlah maksimal. Untuk itu penyuluhan dan tindakan edukatif harus direncanakan, diadakan dan dilaksanakan secara efektif dan intensif kepada masyarakat yang disampaikan dengan sarana atau media yang tepat dan sesuai untuk masyarakat disamping upaya kita dalam pencegahan penyebaran Covid-19.

\section{SIMPULAN}

Modus operandi kejahatan peredaran dan penyalahgunaan narkotika pada masa pandemi Covid 19 diantaranya dengan pengiriman tiga botol narkotika berupa cairan dari China berisi 10 ml yang bertuliskan Hemp Oil yang dicurigai merupakan Tetrahydrocannabinol. Sebelum pandemi, kasus penyalahgunaan narkoba banyak ditemui di tempat-tempat hiburan. Namun, karena tempat hiburan ditutup, penyalahgunaan narkoba kini banyak dilakukan di rumah, apartemen, maupun hotel sifatnya home session. Modus operandi baru peredaran narkotika dalam kuantitas kecil saat ini menggunakan jasa pos dan ekspedisi kebebera daerah di Indonesia. Modus operandi tersebut untuk wilayah sumatera utara marak terjadi, dan rutin digunakan oleh para pelaku peredaran narkotika untuk menyampaikan pesanan narkotika dari pemakai. Modus Pemesanan narkotika saat ini dilakukan melalui tren daring (online) website. Ini menjadi tren bahwa peredaran dan transaksi narkoba dilakukan secara daring dan juga dtemukan di dark web. Kemudian dengan bertransaksi narkotika menggunakan transportasi logistik pertanian, seperti jagung, kelapa, pisang atau beras dengan seolah-oleh mengirimkan barang untuk kebutuhan masyarakat ke suatu daerah.

\section{DAFTAR PUSTAKA}

Abdurrahman, M. (2009). Sosiologi dan Metode Penelitian Hukum. UMM Press.

Adhitya, B. (2020). ANALISIS KETERLIBATAN WANITA DALAM TINDAK PIDANA PEREDARAN NARKOTIKA PADA MASA PADEMI COVID-19. SOL JUSTICIA, 3(2), 249-256.

Azmi, N., \& Rani, F. (2017). Pengaruh Globalisasi Terhadap Peredaran Narkotika di Asia Tenggara Tahun 2011-2015. Riau University.

Beridiansyah. (2020). Narkoba Di Tengah Pandemi Covid 19. Www.Jambi-Independent.Co.Id.

BNN, H. (2020). Ditengah Pandemi Covid-19, Badan Narkotika Nasional Berhasil Ungkap Jaringan Narkotika Internasional Serta Sita Ratusan Kilogram Sabu Dan Puluhan Ribu Butir Ekstasi. Https://Bnn.Go.Id.

Butar-Butar, C., Sahari, A., \& Perdana, S. (2020). Scientific Testimony Terhadap Hukuman Mati Bagi Pelaku Tindak Pidana Narkotika. Journal of Education, Humaniora and Social Sciences (JEHSS), 3(1), 61-69. doi:https://doi.org/10.34007/jehss.v3i1.194

Dewi, C. M. T. (2020). Kasus Narkoba dan Hoaks Meningkat di Jakarta Selama wabah Covid 19. Www.Metro.Tempo.Co.Id.

Efendi, R. (2020). Akal Bulus Sindikat Narkoba Gunakan Bungkus Kopi Gayo. Www.Liputan6.Com.

Humendru, B., Ginting, D., \& Sitorus, R. (2020). Analisis Yuridis Penentuan Jenis Dakwaan Yang Disangkakan Kepada Terdakwa Dalam Perkara Tindak Pidana Narkotika. Journal of Education, Humaniora and Social Sciences (JEHSS), 3(1), 222-226. doi:https://doi.org/10.34007/jehss.v3i1.273

Ibrahim, Johny. (2008). Teori Dan Metodologi Penelitian Hukum Normatif (Surabaya: Bayumedia.

Johny Ibrahim. (2008). Teori dan Metodologi Penelitian Hukum Normatif. Bayumedia.

Lubis, M. (2020). Peran Akademisi dalam Mencegah Peredaran Narkotika di Masyarakat (Sosialisasi Desa Bandar Baru Kecamatan Sibolangit Kabupaten Deli Serdang Provinsi Sumatera Utara). Journal of 
Vol 4, No. 2, November 2021: 650-659

$\begin{array}{lllll}\text { Education, Humaniora and Social } & \text { Sciences } & \text { (JEHSS), } & \text { 2(3), }\end{array}$
doi:https://doi.org/10.34007/jehss.v2i3.138

Mandailing, M. (2020). Polres Tanjung Balai amankan warga jual narkotika di tengah pandemi COVID-19. Https://Sumut.Antaranews.Com.

Marzuki, P. M. (2006). Penelitian Hukum. Kencana.

Millah, I. A. (2020). Penanggulangan Kejahatan Di Masa Pandemi Covid-19 (Dalam Perspektif Kriminologi Dan Viktimologi). Jurnal Komunikasi Hukum (JKH), 6(2), 497-513.

Natalia, S., \& Humaedi, S. (2020). Bahaya Peredaran Napza Pada Masa Pandemi Covid-19 Di Indonesia. Prosiding Penelitian Dan Pengabdian Kepada Masyarakat, 7(2), 387.

Permadi, A. (2020). Dikira Bansos Covid 19, Ternyata Isinya Narkoba. Www.Kompas.Com.

Simangunsong, F. (2014). Penegakan Hukum terhadap Pelaku Tindak Pidana Narkotika (Studi Kasus di Kepolisian Resor Surakarta). RECHTSTAAT, 8(1), 1-10.

Sirait, E.W. \& Rafiqi (2018). Pertimbangan Hakim dalam Menjatuhkan Putusan Tindak Pidana Narkotika Yang Dilakukan Pengedar pada Putusan No: 2071/Pid.Sus/2016/Pn-Mdn), Jurnal Ilmiah Penegakan Hukum 5 (1) 2018: 1-7.

Siregar, F. Y. D. (2020). Aspek Hukum Penyederhanaan Perizinan Badan Usaha di Bidang Lingkungan Hidup dalam Undang-Undang Cipta Kerja. Jurnal Ilmiah Penegakan Hukum, 7(2), 184-192.

TV, R. K. (n.d.). Modus Baru Penyelundupan Narkoba di Masa Pandemi Covid-19. Www.Msn.Com.

Wibowo, A., Eddy, T., \& Sahari, A. (2020). Tindak Pidana Korporasi Bagi Perusahaan Yang Terlibat Dalam Pencucian Uang Hasil Penjualan Narkotika. Journal of Education, Humaniora and Social Sciences (JEHSS), 3(1), 52-60. doi:https://doi.org/10.34007/jehss.v3i1.193

Zulyadi, Rizkan. (2020). Analis Kebijakan Pemerintah Pemerintah Kota Medan Dalam Penanganan Pandemi Covid-19, dalam Buku Segi Hukum Terhadap Implikasi COVID-19 di Indonesia : Hasil Pemikiran Kritis Pimpinan APPTHI, Editor: Ahmad Redi dan Ibnu Sina Chandranegara, Kencana, Jakarta. 